\title{
Self-transcendence: An alternative explanation for voluntourism in developing countries
}

\section{Eddy K, Tukamushaba*}

Department of International Hospitality Management,

Stenden University Qatar,

P. O. Box 336037,

Doha, State of Qatar.

T: +9744888116 Ext.416

M: +97450108950

E-mail: ETukamushaba@stenden.edu.qa

\section{Honggen Xiao}

School of Hotel and Tourism Management

The Hong Kong Polytechnic University, 17 Science Museum Road, TST East, Kowloon

Hong Kong SAR, China

Tel. +852 3400 2250; Fax. +852 23629362

Email: honggen.xiao@polyu.edu.hk

\section{Adele Ladkin}

Department of Tourism and Hospitality, Faculty of Management, Bournemouth University, Dorset House D225, Talbot Campus, Fern Barrow, Poole, BH12 5BB

United Kingdom.

Tel: 01202961891

E-mail: aladkin@bournemouth.ac.uk

* Corresponding author

\begin{abstract}
In recent years, travel associated with volunteering activities has attracted a cross section of people with varying demographic characteristics and aspiration to both developing and developed countries and has been on increase. This paper argues for self-transcendence as an alternative altruistic motivation for some individuals who choose to travel to developing nations destinations which are considered risky as VOLUNtourists. A descriptive research design was used to guide the research process. This study was based on a sample of 501 respondents who had completed their visit to Uganda for various reasons.

Results indicate that, there was no significant association between gender and purpose of the visit, while age group was significantly associated with the purpose of visiting. Most visitors were seeking that which they perceived to be beyond themselves associated with spirituality. Currently most facilities within tourist attractions in Uganda favour the adult age group and it is recommended that special consideration be given to the development of affordable facilities such
\end{abstract}


as accommodation to cater for all age groups in order to continue realising the positive contribution to the potential of tourism in developing countries.

\section{Key words: VOLUNtourism, Travel motivation, Self-transcendence, Uganda.}

Reference to this paper should be made as follows: Tukamushaba, K. E., Xiao, H., and Ladkin,

A. (xxxx) Self-transcendence: An alternative explanation for voluntourism in developing countries. Int. J. Sustainable Society, Vol. xx, No. x, pp. xx-xxx.

Biographical notes: Eddy is an Associate Professor in the department of International Hospitality Management Stenden University Qatar. His research interest is in the areas of destination branding, travel motivation, memorable travel experiences and service quality. Details of some of his publications can be found at: https://www.researchgate.net/profile/Eddy Tukamushaba/info

Honggen is an Associate Professor, at The Hong Kong Polytechnic University. His research interests have been in developing a focused area of research on knowledge development and scientific community in tourism and hospitality, which mainly addresses the tensions of knowledge from the perspectives of theory development, theory and practice, and dissemination of knowledge across language communities. He is co-editor of the Springer (2016) Encyclopedia of Tourism.

Adele is a Professor of Tourism Employment in the Department of Tourism and Hospitality, Faculty of Management, Bournemouth University, UK. Her research interests and publications are in the areas of labour migration, tourism employment and labour issues in the tourism and hospitality. She is currently working on a multidisciplinary research project 'Family Rituals 2.0' funded by the EPSRC, exploring the evolving nature of family rituals in the digital age and the use of technology to support the work-life balance of mobile workers.

\subsection{Introduction}

A considerable number of studies on travel motivation to different destinations have been undertaken by different scholars (Iso-Ahola, 1982; You, O'leary, Morrison and Hong, 2000; Page and Connell, 2006; Hsu, Cai and Wong, 2007; Hsu, Cai and Li, 2010). A number of theories have also been developed and utilized to explain why different categories of people choose to travel or not to certain destinations. One key theory that has been widely adopted in most studies 
of tourism to explain travel motivation is the Maslow’s hierarchy of needs (Maslow, 1943; 1964; 1970). Maslow's motivation theory is premised on the understanding that motivation as a human factor is influenced by a dynamic process that involves the internal psychological factors in the form of needs, wants and goals (Pearce, 1982; 1993) and that human needs are in form of a hierarchy of five levels where one must move to higher level after first fulfilling those needs at the lower levels.

Fodness (1994) argues that motivation as a dynamic process has the ability to cause an imbalance within individuals' minds and bodies, which may result in actions directed towards releasing the tensions created in a bid to satisfy the existing needs, wants or goals. Maslow (1943) argued that human needs ranged from basic to self-actualisation. He opined that the human needs were arranged in a hierarchical manner with five levels. This theory posits that for an individual to move up from one level to another, the lower needs such as food, shelter, need to be satisfied first.

A number of tourism research strands have been developed based Maslow's hierarchy of needs such as the travel career ladder (Crompton, 1979; Pearce, 1993; Pearce and Lee, 2005; Ryan, 1998). For example, Crompton (1979) argues that it is possible to describe who travels, when they travel, where they choose to travel to, and how they get to reach the chosen destination. These questions can easily be answered by scrutinising the social and economic characteristics of the tourist. However, answering the question "why" which is at the centre of all tourist behaviour has been a challenge up to the present day (cited in Fodness 1994, p. 556).

Additionally, Mansfeld (2000) argues that understanding the motivation of people to travel leads one to ascertain why they choose particular destinations and the behaviour they demonstrate. Gnoth (1997) adds to the debate of the importance of understanding travel 
motivation in order for destination managers to help them develop abilities to influence tourists’ expectations.

In recent years travel to both developed and developing countries for reasons related to volunteering has been on the increase (Sin, 2009; 2010; Zoe and Ali, 2011; Conran, 2011; Wearing and McGehee, 2013; Zeddies, 2015). Reasons mostly advanced by those involved in volunteering activities include but are not limited to performing charity work such as offering free medical services to poor communities (McLennan, 2014), education programs at all levels of education with the aim of developing skills that would improve the social economic status of poor communities (Stoddart and Rogerson, 2004; McLennan, 2014; Zeddies and Millei, 2015), offering support to conservation of wildlife (Sujarittanonta, 2014), providing help to reconstruct disaster stricken areas (Zahra and McIntosh, 200; Lo and Lee, 2011) and religious based activities (McGehee, 2014). It is common to find a group of volunteers also taking an opportunity to visit different tourism attractions within the country they are visiting or taking part in different tourism activities during their leisure time (McKee, et al ,... why people volunteer, par. 3). This has led to voluntourism being recognised as an alternative form of tourism (McGehee, 2014).

Daldeniz and Hampton (2010) categorises individuals who travel to developing countries for purposes of volunteering in two groups based on their motivation to travel, lifestyle and living conditions. The first category named "VOLUNtourists" was assumed as having their main motivation for undertaking a longer term commitment to participate in a development project based on altruistic motives associated with helping the local communities in question. The second category of "volunTOURISTS" describes those who travel to developing countries and tourism activity itself is the main driver for them 
to accept a long-term volunteer work situation. For purposes of this study, the category categorized as "VOLUNtourists" will be addressed.

Given the importance and growth of voluntourism in general the world over, there is need to explore the deeper meaning attached to volunteering and how this activity facilitates tourism development to particular destinations. Whereas it has been argued that travel motivation plays a central role in satisfaction formation (Gnoth, 1997), the underlying intrinsic motivation at the being level to engage in volunteering has not been fully explored in the current literature. According to Lucas (2009), being level describes the state of human mind that enables individuals to achieve true happiness. Hinged in positive psychology, being level defines individuals with the ability to combine different aspects of their lives to achieve happiness through the emotions of pleasure and contentment. It is posited in this paper that individuals whose main motivation to travel is to volunteer and get involved in tourism activities as a secondary motivation (VOLUNtourists) defines individuals striving to get to the being level.

Exploring travel motivation related to volunteering in the context of a developing economy, and providing a deeper meaning to VOLUNtourism as described for purposes of this paper is important for tourism development in developing economies (Brown, 2005). Secondly, there is a lack of a theoretical explanation as to why individuals travel for volunteering in countries generally perceived to be poor and risky to visit. Thirdly, an understanding of whether some demographic characteristics such as gender and age are associated with the purpose of visiting for purposes of volunteering would provide insight to travel motivation theories and tourism destination development in general.

This study builds on Maslow's hierarchy of needs theory, and extends it to cover the concept of self-transcendence (Koltko-Rivera, 2006). Self-transcendence is a personality trait 
associated with experiencing spirituality and having unique feelings of being one with the universe (De Fruyt, Van De Wiele and Van Heeringen, 2000). In this paper self- transcendence is used to describe individuals who travel with the prime reason of seeking to further a cause beyond the self and to experience a communion beyond the boundaries of the self through peak experience. It further describes people irrespective of age and gender who travel to volunteer while also enjoying the benefits associated with travel to exotic destinations.

In summary, the following research questions are posed to guide the study. What is deeper meaning attached to volunteering and how does volunteering facilitates tourism development to a particular destination? What is the possible explanation as to why individuals travel for volunteering in countries generally perceived to be poor and risky? What is the association of age and gender with the reasons of visiting Uganda?

\subsection{Literature review}

Early studies of motivation were conducted by Maslow (1943) in his seminal theory of human motivation and his subsequent studies such as motivation and personality (Maslow, 1954, 1970). The earlier version of Maslow's theory of motivation highlights five main human motivators as being arranged in a hierarchy beginning with physiological needs to safety; love and belonging, esteem and finally self- actualization. Maslow's original conceptualization was that human needs are arranged in a hierarchy where progression from one need to the next occurs as each need is satisfied. However, the theory as its original form does not represents individuals' age, gender in the progression from lower to higher level needs especially at the being level.

Different scholars in tourism research have made an attempt to utilize the Maslow's conceptualization of motivation to establish what motivates different people to travel to different 
destinations and what makes them become involved in tourism activities offered by different destinations (Cohen, 2004; Iso-Ahola, 1982; Pearce and Lee, 2005; Ryan, 1998). Whereas variations do exist in the findings obtained, the common agreement from most of tourism studies is that tourism motivation is linked to escape, prestige and relaxation which are considered to be higher level motivational needs at the being -“true” self-level (Crompton, 1979; Pearce and Lee, 2005; Ryan, 1998, p. 937).

However, Wright (2013) argues that Maslow’s original explanation of human motivation as being based on hierarchically arranged five levels of needs does not represent all individuals. For example, age, gender and social economic status of individuals have been found to influence human behavior such as responsiveness to volunteer activities while visiting a particular destination. Literature has propagated an argument that there are only five levels in the hierarchy of needs starting with physiological basic needs, safety, love and belonging, esteem to selfactualisation. The growth of the concept of VOLUNtourism requires an alternative explanation which is beyond self -actualisation. In this paper, it is argued that self-actualisation is not at the apex of the Maslow's hierarchy of need but rather self-transcendence (Koltko-Rivera, 2006).

The original conceptualization by Maslow's hierarchy of needs that climaxed with selfactualization was hinged on the understanding that individual goals were aimed at attaining psychological maturity or good health, a predominant phenomenon at that time (Ryan, 1998). Koltko-Rivera (2006) provides evidence that Maslow's motivational hierarchy is not complete without the sixth level of self-transcendence.

Unlike the original climax of self-actualization, individuals at self-transcendence level of motivation, some individuals seek to further a cause beyond self and this may include people whose travel motivation is to provide service to others. In tourism studies, this has been 
exhibited by individuals whose main motivation to travel to long haul destination is to offer volunteering services whilst at the same time getting involved in other tourism activities which has led to the development of a new form of tourism known as voluntourism (Hawkins, Lamoureux, and Clemmons, 2005; Woosnam and Lee, 2011; Sin, 2009).

Individuals whose main reason to travel is to experience self-transcendence can be identified by what motivates them to travel to particular destinations not others. For example, Willson, McIntosh, and Zahra (2013) identify a number of characteristics linked to selftranscendence such as devotion to an ideal situation involving art and truth or a cause such as travelling for religious faith or spirituality; pursuit of science; environmentalism through ecotourism and experiencing a communion beyond the boundaries of self through peak experiences (p.153). These kinds of travel motivations aid the generation of peak experiences important in memorable travel experience formation (Quan and Wang, 2004).

The peak experiences may involve mystical and certain experiences with nature, aesthetic, sexual and other transpersonal experiences in which the person experiences a sense of identity that transcend the personal self. The self-transcendence level was added after realizing that self- actualization was not possible in young people or people who were still developing, because their motivation was different from older people who have already attained the lower needs.

However, self-transcendence could be attained by all people across all the ages when higher level motivations at the being level are at play. This is shown for example in the trend of volunteers being the youth and the old, offering services at different levels while visiting particular destinations. Table 1 provides a modified version of Maslow's hierarchy of needs with the highest level being self-transcendence. 


\section{*********INSERT TABLE 1 HERE}

This study explores what Maslow described as peak experiences, which include mystical, aesthetic, and emotional experiences through an all-embracing construct of memorable travel experiences. The self-transcendence motivations conceptualization by Maslow (1964, 1970) describes being-cognition which is linked to the being theory that explains positive emotions of pleasure, happiness and contentment. All these experiences are sought by different tourists at different levels and no study in tourism has explored how high level travel motivations at the being level influence tourists' perceptions and how these higher travel motivations memorable travel experience.

Among the early scholars who considered motivation theories in tourism include Montinho (1987). Montinho defines motivation as “... a state of need, a condition that exerts a push on the individual towards certain types of action that are seen as likely to bring satisfaction” (p.16). This satisfaction can be manifested in terms of physiological and psychological needs of people (Berkman, Lindquist, and Sirgy, 1997). Tourism motivation in earlier tourism studies was further conceptualized as being a dynamic process which involves internal psychological factors in form of needs and wants that generate a state of tension or disequilibrium within individuals (Crompton and MacKay, 1997). Motivation has often been considered as inner state that directs and boosts human behavior (Kassin, 2004; Li and Cai, 2012). This study conceptualizes travel motivation in respect to a tourist as a consumer of tourism products, places, and experiences.

While contributing to motivation research in tourism, Dann (1981) provided a working definition of travel motivation as "a meaning state of mind which adequately disposes an actor or 
a group of actors to travel and which is subsequently interpretable by others as a valid explanation for such decision” (p.205). However, the second component of the definition which required a meaningful state of mind to be interpretable by others in order to be called a valid explanation for such a decision was contested by Iso-Ahola (1982). Iso-Ahola advances an argument that for any definition of tourism motivation to be meaningful, both physiological and psychological processes must be included. He further notes that motivation is "purely a psychological concept not a sociological one” (p. 257).

\subsection{Travel motivation in travel and tourism research}

Despite the weakness that is associated with Maslow's theory of motivation, especially that advances the argument that human needs are not necessarily fulfilled in a hierarchical order and that behavior may be initiated for more than one need at a time (Goebel and Brown, 1981), the theory has nevertheless formed a basis for other motivation studies notable of which is the travel career ladder. The travel career ladder explains how individuals evolve through a travel career as they age (Pearce and Lee 2005). Pearce and Lee (2005) argue that a similar set of motivational factors of relaxation, stimulation, relationship, self-esteem and development and fulfillment can be used to describe the travel career that an individual will follow as they age.

Furthermore, Cohen (2004) provides a clear description of why people travel and what travel means to different people. Cohen argues that people who seek familiar destinations are motivated by need for relaxation and rest through recreation. Their needs and behavior change as one seeks for destinations that provide novelty where travel experience is at a higher emotional level of experience. Furthermore, individuals who travel in order to seek novel experiences tend to choose destination that would provide them with an opportunity to experience different 
lifestyles and living like natives (Brown, 2005; Wearing, 2001). This set of aspirations, would therefore require such destinations to provide authentic tourism product and services.

In tourism and hospitality studies, products and services within a destination that make individuals develop a sense meaning to life vary from one individual to another. This variation has been linked to the human ability to create intrinsic emotions that are capable of forming memorable experiences (Wang, 1999). Cohen (2004) conceptualisation of tourists' travel motivation identified five characteristics various people who travel to different destinations. Ranging from novelty to familiarity and authentic to non- authentic experiences, different people travel in order to recreate through resting, playing and relaxing; Escape from familiar home country environment; Look for new meaning in life; Experience different lifestyles; and to live like natives. From the five travel motivations identified, travel related to experiential and existential reasons fit well into the description of self-transcendence a key trait of VOLUNtourists.

The identified travel motivations by Cohen (2004) are in tandem with Iso-Ahola’s (1980) social- psychological model of tourism motivation. Iso-Ahola suggests that people are motivated to travel by both "approach (seeking) and avoidance (escaping)" components present in leisure motivation in general (pp. 312-313). The two travel motivation forces of seeking and escaping have been found to be key influencers of different behaviors in individuals such as destination choice seeking behavior (Snepenger, King, Marshall, and Uysal, 2006).

The social-psychological model of tourism motivation shows for example that if an individual escapes the personal pressures such as troubles, problems, difficulties and failures, and or the interpersonal world such as family members, co-workers, relatives, friends and neighbors, he may seek personal rewards such as learning about other people's culture, rest and 
relaxation, prestige, ego enhancement, and interpersonal rewards such as varied and increased social interaction with friendly natives, members of the travel group and with old friends in the destination visited (Iso-Ahola, 1982).

Whereas several researchers argue that individuals especially from the western world with leisure time at their disposal travel to long haul destinations for reasons related to selfactualization (e.g., Dumazedier 1967, Krippendorf 1987, Mill and Morrison, 2002, Parker 1983), recent studies have shown that increasingly the dynamic relationship between the real and ideal self of human beings continue to change and this has been exhibited by increasing quest to travel related to service above self associated with voluntourism in order to achieve a state of stability (Galley and Clifton, 2004; Goosens, 2000).

This study argues for push factors which represent long lasting characters that are intrinsic in nature other than pull factors at the destination that motivate VOLUNtourists (Knollenberg, McGehee, Boley and Clemmons, 2014). The emotional nature associated with self- transcendence makes it a viable alternative explanation for the growth of travel to long-haul destination for reasons associated with VOLUNtourism (Barbieri, Santos and Katsube, 2012; Conran, 2011; Lyons, Hanley, Wearing, and Neil, 2012).

Travelling to destinations that are considered risky requires unique travel motivations. It is argued in this paper that, the conducive environments provided by developing economies help individuals to appreciate their privileged position provided by developed economies. These experiences that influence the development of inner values of individuals motivate them to offer service above self as global citizens with the aim of creating a difference.

It is activities related to volunteering that tend to be remembered most, and the same activities may be repeated in other setting for people who exhibit self-transcendence trait. This 
could explain why VOLUNtourism has been increasing despite the negative perceptions associated with poverty, disease, war, and natural calamities common in developing economies and that therefore require most volunteer services (Tukamushaba, Xiao, and Ladkin, 2015).

It may be concluded that intrinsically motivated individuals such as VOLUNtourists do not rationalise their involvement in combining tourism and volunteering activities as a means to satisfy the higher level needs. They tend to volunteer in order to serve above self often based on spirituality principles and motivation to create a difference in disadvantaged societies of the world.

\subsection{Methods}

A descriptive research design was used to guide the research process. For this study, the population was based on the previous figures of international travelers who visited Uganda between 2008 and 2013. An average of 844,000 tourists based on tourist arrivals to Uganda for a period of five years was used to estimate the sample size. According to Krejcie and Morgan (1970), the sample of 384 is adequate for a population equal or over to 1 million at 95\% confidence level. A sample of 501respondents for this study was considered adequate. This is because larger sample sizes are always preferable and therefore the results can be relied on to informing policy and tourism development decisions.

Data was collected between January and April, 2012 using the transit area of the Entebbe International Airport. The "next-to-pass" method procedure was used to identify potential respondents who were willing to participate in the survey after completing immigration procedures (Chen and Hsu, 2000). Data was collected at different times of the day and even days of the week to cover different airline departure times and days. This ensured a systematic 
spread of respondents from whom data was collected. A Chi-square test was used to test whether gender and age of the respondents were associated with the reasons for visiting Uganda.

\subsection{Key findings}

Different respondents' socio-demographic characteristics including; gender, marital status, age group, occupation, education level, travel cost, travel companion, travel arrangement, purpose of visiting Uganda and country of origin were collected. Gender distribution was nearly equal with males at $50.1 \%$. Most of respondents were single with $47.5 \%$ which correspondents to the majority of the respondents being in the age bracket of $20-29$ with $31.5 \%$. The detail covering the other categories within each socio-demographic characteristic is shown in Table 2.

************INSERT TABLE 2 HERE***************

\subsection{Purpose of visit to Uganda}

Results from a question that was meant to establish the reasons why the respondents were visiting Uganda are as shown in Table 3.

**************INSERT TABLE 3 HERE*************

As shown in Table 3, the question that sought the reasons for visiting Uganda, apart from traveling for holiday with $44 \%$, and visiting friends and relatives with $25.9 \%$ those whose main purpose was to volunteer but at the same time got involved in tourism activities were at $24.4 \%$. A further analysis of the travel arrangements revealed that about $13 \%$ of the total number of 
respondents, were organized by a volunteer company and a number of the respondents who were independent travellers were most involved in volunteer activities. Table 4 shows the breakdown of travel arrangements.

**************INSERT TABLE $4 \mathrm{HERE} * * * * * * * * * * * *$

\subsection{The association between gender and age and the reason for visiting Uganda.}

In order to establish whether gender of the respondent was associated with the reason or motive for visiting Uganda, a Chi-square test of association was conducted. Results indicated that there was no significant association between gender of the respondents and the reasons for vising Uganda $\chi^{2}(3)=.732, p>.05$, while age group was significantly associated with the purpose of visiting $\chi^{2}(15)=34.439, p<.05$ with Cramers $V=.151, \mathrm{p}<.05$ which means the effect size of this observation though relatively weak was significant.

\subsection{Discussion, conclusion and policy implications}

The main objective was to establish the key underlying reasons that motivate individuals who travel to destinations in developing economies and are considered risky. The results in Table 3 with visitors who indicated that their main purpose to visit Uganda was to volunteer (24.8\%) and those whose purpose to visit Uganda was associated with religion (4\%) provides an explanation for what was originally linked to self-actualization. This study further established that within those who identified themselves as having visited Uganda with the main objective of volunteering, but used the opportunity to get involved in tourism activities referred to as VOLUNtourists in this paper. 
This study associates this group of individuals as being motivated in order to fulfill a higher psychological need that is beyond self-actualization. Under the modified Maslow's hierarchy of needs these individuals would be categorized under self-transcendence. KoltkoRivera (2006) provides evidence of the existence of a higher motivation factor of selftranscendence which has been found to be exhibited by individuals who predominantly travel for the purpose of volunteering.

According to Koltko-Rivera (2006), self- transcendence is associated with higher level needs that seek to further a cause beyond the self and to experience a communion beyond the boundaries of the self through peak experience. Barbieri, Santos, and Katsube (2012) in the study related to voluntourism in Rwanda found that participants were mainly motivated by intrinsic motivation factors related to self-development, bonding with local people, and experiencing the local lifestyle.

In the case of Uganda, the majority of volunteers were involved in activities based on religious arrangements followed by the need to help the poor communities through different education and training programs. This was mainly through providing skills that would be sustainably managed by the recipients. It was further found out that, the majority were seeking to adopt children from poor communities. Voluntourism in general was positively contributing to the development of tourism and was a viable alternative form of tourism. Irrespective of the reason given by those whose main reason was to volunteer, most respondents reported to have had benefited especially in the improvement of their spiritual wellbeing.

These findings agree with Stebbins and Graham (2004) argument that volunteering has the benefit of providing "a sense of purpose, provokes serious contemplation, encourages 
concern for others and provides the opportunity to further an interest and above all generates a sense of deep personal fulfillment” (p.484). All these benefits identified are characteristics of individuals who find fulfillment in life through service above self which describes selftranscendence. Uganda provided them with an opportunity to experience what they would not have otherwise experienced while in their own countries.

The emerging market of VOLUNtourism in Uganda has the potential to increase the number of tourists who travel responsibly (Brown, 2005; Daldeniz, and Hampton, 2010). For example, Lepp (2008) reports on how tourism was developed around the Kibale Forest National Park within the local communities in the Bigodi village area with the help of a US Peace Corp volunteer (PCV). The volunteer in this case realized the opportunity that the swamp in the area he was visiting provided for tourism development because it was a home to different bird species that he used to enjoy viewing in his free time. As a result, the cooperative named the Kibale Association for Rural and Economic Development, or KAFRED was developed into a success story for the communities around the Kibale Forest National Park.

The results in this study indicated that gender has no significant association with the purpose of the visit $\chi^{2}(3)=.732, p>.05$, while age group was significantly associated with the purpose of visiting $\chi^{2}(15)=34.439, p<.05$. This finding that age is significantly associated with tourist motivation to travel is in agreement with Jönsson and Devonish (2008) study which concluded that age does count in respondent's motivation to travel using the case of travel to Caribbean Islands of Barbados. The same study also showed that gender did not emerge as an important determinant of travel motivation. 
The finding in this current study about Uganda provides further evidence that travel related to volunteering provides a much higher extrinsic value explained by self-transcendence and Uganda is endowed with different activities and has potential to provide this value to VOLUNtourists especially in the advancement of spirituality of individuals. This finding further agrees with MacDonald and Holland (2002) study that established an independent subscale labeled spiritual and religious beliefs as part of self-transcendence construct.

Findings indicate that a considerable number of the surveyed tourists were visiting Uganda in order to volunteer (25\%) and specifically those who exclusively were visiting for reasons associated with religion and spirituality was remarkable. This observation poses business opportunities for local communities living around areas designated for religious activities. Therefore Ugandans living near different attractions such as spiritual sites should exploit opportunities this market provides by setting up organized small shops with souvenirs depicting different aspects of spirituality needs of visitors. Learning from the case of KAFRED a success story of tourism development through a Peace Corp volunteer, providing discounted packages for such groups would enable them to visit protected areas or selected recreation centers within the communities in which they are volunteering (VolunTourism.org, 2012).

The development of tourism products such as theme parks within each of the four main regions of Uganda, with different themes based on the rich cultural diversity in Uganda, would be a good starting point to tap into this market. Developing facilities such as accommodation that are affordable by all age groups would further motivate volunteers to visit Uganda and therefore reap the benefits associated with volunteerism in all aspects of life in local communities. 
In addition to volunteering, the travel motivation for spiritual reasons also featured prominently within the sample studied, with $4.4 \%$. This is also another area that has been largely ignored and yet it could be exploited in order to increase tourism arrivals. In the case of Uganda, travel related to higher level motivation reflected under Maslow's new conceptualization that included self-transcendence occurred through VOLUNtourism (Koltko-Rivera, 2006).

The spiritual component is under the educational component that describes individuals or groups of people that travel to experience a wide range of human activities for personal gratification but also serving to benefit the local communities who are disadvantaged (Hawkins, Lamoureux, and Clemmons, 2005). Additionally, the spiritual component is related to paying pilgrimage to religious sites. For example, in Uganda, every year on June 3rd, at Namugongo shrine, people from different countries come to commemorate the 13 saints who were burnt alive for their faith which is recognized on the Ugandan calendar as Uganda Martyrs day.).

Seeking intrinsic rewards such as a sense of fulfillment was another important motivation factor for tourists who visited Uganda. This was mainly for the tourists whose main reason to visit Uganda was to volunteer, and those who were visiting for reasons associated with spirituality. This finding is in agreement with Iso-Ahola's (1982) and Willson, McIntosh and Zahra's (2013) assertion that individual's perception of leisure activities has the potential to create satisfaction because having leisure provides certain intrinsic rewards, such as feelings of mastery and competence, and helps them leave the routine environment behind themselves.

Facilitators of voluntourism could improve participants' tourism experience if they understood such an intrinsic travel motivation (VolunTourism.org, 2012). Travel associated with volunteering and spiritual reasons all together accounted for $29.1 \%$ of the 
surveyed respondents in this study. This provides another area of tourism opportunity where particular tourism products could be designed to allow mutual benefit between the local community and the volunteers themselves. The understanding of support activities that best suits the local communities is likely to enhance the VOLUNtourists' experience and in the process cement the notion of global citizenship. Additionally, promotion of community-based tourism would attract all age groups. It is asserted that this activity would clearly assist to maximize the mutual benefits of individuals seeking self-transcendence.

Though this study provided a bench mark of using individual self-transcendence motivation as an alternative explanation for VOLUNtourism in developing countries, using forced response format questions may have limited the exploration of other intrinsic travel motivation. It is recommended that qualitative research methods of data collection such as indepth interviews be used in future studies using other developing countries to establish whether self-transcendence is a consistent possible alternative explanations for individual's motivation to travel to developing countries to get involved in volunteering activities and at the same time participating in tourism activities through what is now recognized as VOLUtourism.

Although a Chi-square test tested relationships between gender/age with reasons for visiting Uganda, other studies to establish the possible associations between spirituality, selftranscendence, gender, age, and volunteering should be carried out. In particular one question to consider would be: How do individual motivations to volunteer in a "risky" developing country destination differ from those who volunteer in countries perceived as being less risky? 


\section{References}

Barbieri, C., Santos, C. A., and Katsube, Y. (2012) Volunteer tourism: On-the-ground observations from Rwanda, Tourism Management, Vol. 33, No.3, pp. 509-516.

Beerli,A., and Martı'n,J.D. (2004) Tourists' characteristics and the perceived image of tourist destinations: A quantitative analysis - a case study of Lanzarote, Spain, Tourism Management, Vol. 25, pp. 623-636.

Berkman, H., Lindquist, J.,and Sirgy,M. J.(1997) Consumer behavior: Concepts and marketing strategy, NTC Business Books, Lincolnwood.

Brown, S. (2005) Travelling with a purpose: Understanding the motives and benefits of volunteer vacationers, Current Issues in Tourism, Vol. 8, No. 6, pp. 479-496.

Cohen, E. (2004) Backpacking: Diversity and change, in Richards, G. and Wilson, J. (Eds.), The global nomad: Backpacker travel in theory and practice, Channel View Publications, Clevedon, pp.43-59.

Conran, M. (2011) They really love me! Intimacy in volunteer tourism, Annals of Tourism Research, Vol.38, No. 4, pp.1454-1473.

Crompton, J. L. (1979) An assessment of the image of Mexico as a vacation destination and the influence of geographical location upon the image, Journal of Travel Research, Vol. 17, No.4,pp.18-24.

Crompton, J . L., and McKay, S. L. (1997) Motives of visitors attending festival events, Annals of Tourism Research, Vol.24 No.2, pp.425-459.

Daldeniz, B., and Hampton, M. P. (2010) VOLUNtourists versus volunTOURISTS: a true dichotomy or merely a differing perception? Benson, A. M. Eds., Volunteer Tourism: Theoretical frameworks and practical applications, pp.30-41, Routledge, London. 
Dann, G. M. (1981) Tourist motivation: An appraisal, Annals of Tourism Research, Vol.8 No.2, pp.187-219.

De Fruyt, F., Van De Wiele, L. and Van Heeringen, C. (2000) Cloninger's psychobiological model of temperament and character and the five-factor model of personality, Personality and Individual Differences, Vol.29, No.3, pp.441-452.

Dumazedier, J. (1967) Toward a society of leisure, New York: Macmillan.

Fodness, D. (1994) Measuring tourist motivation. Annals of Tourism Research, Vol.21No.3, pp.555-581.

Galley, G. and Clifton, J. (2004) The motivational and demographic characteristics of research ecotourists operation Vallacea volunteers in South East Sulewasi, Indonesia, Journal of Ecotourism,Vol.3, No.1, pp.69-82.

Gnoth, J.(1997)TourismMotivationandExpectationFormation,AnnalsofTourismResearch,Vol.24, No.2, pp.283-304.

Goebel, B. L., and Brown, D. R. (1981)Age differences in motivation related to Maslow's need hierarchy, Development Psychology,Vol.17, No.6,pp.809-815.

Hawkins, D., Lamoureux, K., and Clemmons, D. (2005) Voluntourism as a catalyst for developing the potential of tourism destinations, Tedqual, Vol.7, No.1, pp.13-17.

Hsu, C.,Cai, L.,and Wong,W.(2007) A model of senior tourism motivation: Anecdotes from Beijing and Shanghai, TourismManagement,Vol.28, No.5,pp.1262-73.

Hsu, C., Cai, L. A., and Li, M. (2010) Expectation, motivation, and attitude: A tourist behavioral model, Journal of TravelResearch,Vol.49, No.3, pp.82-296

Iso-AholaS. E. (1982) Toward a social psychological theory of tourism motivation: A rejoinder, Annals of Tourism Research,Vol.9, No.2,pp.256-62. 
Jönsson, C., and Devonish, D. (2008) Does nationality, gender, and age affect travel motivation? A case of visitors to the Caribbean Island of Barbados, Journal of Travel and Tourism Marketing, Vol.25, No.3-4, pp.398-408.

Kassin,S.(2004)Psychology, 4 ed., PrenticeHall, UpperSaddleRiver.

Knollenberg, W., McGehee, N. G., Boley, B. B, and Clemmons, D. (2014) Motivation-based transformative learning and potential volunteer tourists: Facilitating more sustainable outcomes, Journal of Sustainable Tourism, Vol.22, No.6, pp. 922-941.

Koltko-Rivera, M.E. (2006) Rediscovering the later version of Maslow's hierarchy of needs: Self-transcendence and opportunities for theory, research, and unification, Review of General Psychology,Vol.10, No. 4,pp.302-317.

Krejcie, R., and Morgan, D. (1970). Determining sample size for research activities, Educational and Psychological Measurement, Vol.30,pp.607-610.

Krippendorf, J. (1987) The holiday makers: Understanding the impact of leisure and travel, Heinemann-Butterworth, London.

Lepp, A. (2008) Tourism and dependency: Analysis of Bigodi village, Uganda, Tourism Management, Vol.29, No.6, pp.1206-1214.

Li, M., and Cai, L. A. (2012)Theeffectsofpersonalvaluesontravelmotivationandbehavioral intention, Journal of Travel Research,Vol.51, No.4,pp.473-487.

Lo,A.S., and Lee, C.Y. (2011) Motivations and perceived value of volunteer tourists from Hong Kong,Tourism Management,Vol.32, pp.326-334.

Lucas (2009) Being: Your happiness, pleasure, and contentment, Hayden-McNeil, at United States of America. 
Lyons, K., Hanley. J., Wearing, S., and Neil, J. (2012) Gap year volunteer tourism: Myths of global citizenship? Annals of Tourism Research, Vol.39, No.1, pp.361-378.

Mansfeld.Y. (1992) From motivation to actual travel, Annals of Tourism Research, Vol.19, No.3,pp.399-419.

Martı'n, H. S., and Rodrı'guez del Bosque, I.A. (2008) Exploring the cognitive-affective nature of destination image and the role of psychological factors in its formation, Tourism Management, Vol.29, pp.263-277.

Maslow, A.H. (1943) A theory of human motivation. Psychological Review, Vol.50, No.4, 370396.

Maslow, A.H. (1954). Motivation and Personality, Harperand Row, NewYork.

Maslow, A.H. (1970) A theory of human motivation, Carr, L. (Eds.): Motivation and personality, $3^{\text {rd }}$ ed., pp.15-31,HarperandRow, NewYork.

Maslow, A. H. (1964). Further notes on the psychology of being. Journal of Humanistic Psychology,Vol.4 No.1,pp.45-58.

MacDonald, D. A., and Holland, D. (2002)Examination of the psychometric properties of the temperament and character inventory self-transcendence dimension, Personality and Individual Differences, Vol.36, No.6, pp.1013-1027

McGehee,N.G. (2014) Volunteer tourism: evolution, issues and futures. Journal of Sustainable Tourism, Vol.22, No.6, pp.847-854

McGloin, C., and Georgeou, N. (2015) Looks good on your CV: The sociology of voluntourism recruitment in higher education, Journal of Sociology,1-

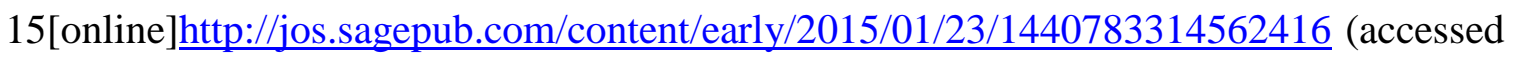
26 April 2016). 
McKee, T.(n.d) Why people volunteer: The top three reasons people volunteer,[Online] from: http://www.volunteerpower.com/articles/Why.asp(accessed on 12 October, 2015).

McLennan, S. (2014) Medical voluntourism in Honduras: 'Helping' the poor? Progress in Development Studies,Vol.14, No.2, pp.163-179.

Mill, A. S., and Morrison, A M. (2002) The tourism systems: An introductory text, KendallHunt, Dubuque.

Montinho, L. (1987) Consumer behavior in tourism, European Journal of Marketing,Vol.21,No.10,pp.5- 44.

Oppermann, M. (1995) Travel life cycle, Annals of Tourism Research, Vol.22.No.3, pp.535-552.

Page, S. and Connell, J. (2006) Tourism: A modern synthesis, Thomson Learning, Toronto.

Parker, S. (1983). Leisure and work. George Allen and Unwin, London.

Pearce, P. (1982) The social psychology of tourist behaviour, Pergamon, Oxford.

Pearce, P. (1993) Fundamentals of tourist motivation, Pearce, D.G.and Buttler,R.W. (eds.),Tourism Research, Critiques and Challenges,pp.113-134,Routledge, London.Pearce, P. L., and Lee, U.(2005) Developing the travel career approach to tourist motivation, Journal of Travel Research,Vol.43, No.3,pp.226-37.

Phelan , K. V. (2015) Elephants, orphans and HIV/AIDS, Worldwide Hospitality and Tourism Themes, Vol.7, No.2, pp.127-140.

Quan, S., and Wang, N. (2004) Towards a structural model of the tourist experience: An illustration from food experiences in tourism, Tourism Management, Vol.25, No.3, pp.297-305.

Ryan, C. (1998) The travel career ladder: An appraisal, Annals of Tourism Research, Vol.25, No.4, pp.936- 957. 
Sin, H. L. (2009) Volunteer tourism - “Involve me and I will learn”? Annals of Tourism Research, Vol. 36, No.3, pp.480-501.

Sin, H. L. (2010)Who are we responsible to? Locals' tales of volunteer tourism,Geoforum,Vol.41, pp. 983-992.

Snepenger, D., King, J., Marshall, E., and Uysal, M. (2006) Modeling Iso-Ahola’s motivation theory in the tourism context, Journal of Travel Research,Vol.45, No. 2,pp.140-149.

Sujaruttanonta, L. (2014) Voluntourism product development and wildlife conservation for Thailand, Worldwide Hospitality and Tourism Themes, Vol.6, No.1, pp.40-50.

Stebbins, R. A., and Graham, M. (eds.) (2004) Volunteering as leisure, leisure as volunteering: An international assessment, CABI,Oxon.

Tukamushaba, K. E., Xiao, H., and Ladkin, A. (2015) Self-transcendence: An alternative explanation for voluntourism in developing countries. Paper presented at the $3^{\text {rd }}$ International Conference on Emerging Research Paradigms in Business and Social Sciences(ERPBSS), 24-26 November, 2016, Park Hyatt Dubai, Dubai Creek

Wang, N. (1999 )Rethinking authenticity in tourism experience, Annals of TourismResearch,Vol.26, No.2,pp.349-370.

Wearing, S. (2001). Volunteer tourism: Experiences that make a difference. CABI, Wallingford: Wearing, S., and McGehee, N. G. (2013) Volunteer tourism: A review, Tourism Management, Vol. 38, pp. 120-130.

Willson, B. W., McIntosh, A. L., and Zahra, A. L. (2013) Tourism and spirituality: A phenomenological analysis, Annals of Tourism Research, Vol.42, pp.150-168.

Woosnam, K. M., and Lee,Y.J.(2011)Applying social distance to voluntourism research. Annals of Tourism Research, Vol.38, No.1, pp.309-313. 
Wong, J., Newton,J. D., and Newton, F. J. (2014) Effects of power and individual-level cultural orientation on preferences for volunteer tourism, Tourism Management,Vol.42, pp.132140.

Wright, H. (2013) Volunteer tourism and its (mis)perceptions: A comparative analysis of tourist/host perceptions, Tourism and Hospitality Research, Vol.13, No.4, pp.239-250

You, X., O'leary, J., Morrison, A., and Hong, G. (2000) A cross-cultural comparison of travel push and pull Factors, International Journal of Hospitality and Tourism Administration,Vol.1, No.2,pp.1-26.

Zahra, A., and McIntosh, A. J. (2007)Volunteer tourism: Evidence of cathartic tourist experiences, Tourism Recreation Research, Vol.32 No.1, pp.115-119.

Zoe, A., and Ali, B. (2011) Understanding voluntourism: A Glaserian grounded theory study, Benson, A. M. Eds., Volunteer Tourism: Theoretical frameworks and practical applications,pp.9-29, Routledge, London.

Zeddies, M. (2015) It takes a global village: Troubling discourses of global citizenship in United Planet's voluntourism, Global Studies of Childhood,Vol.5, No.1,pp.100-111. 
Table 1 A modified version of Maslow's hierarchy of needs

\begin{tabular}{ll}
\hline Motivational level & Description of person at this level \\
\hline Self-transcendence & Seeks to further a cause beyond the self and to experience a \\
& communion beyond the boundaries of the self through peak \\
& experience. \\
Self-actualization & Seeks fulfillment of personal potential. \\
Esteem needs & Seeks esteem through recognition or achievement. \\
Belongingness and love needs & Seeks affiliation with a group. \\
Safety needs & Seeks security through order and law. \\
Physiological (survival) needs & Seeks to obtain the basic necessities of life. \\
\hline Source: Koltko-Rivera, (2006, $\boldsymbol{p .}$ 303)
\end{tabular}


Table 2 Socio-demographic characteristics of respondents $(\mathrm{N}=501)$

\begin{tabular}{llcc}
\hline $\begin{array}{l}\text { Demographic } \\
\text { Variables }\end{array}$ & & Frequency & Percentage (\%) \\
\hline Gender & Male & 251 & \\
& Female & 250 & 50.1 \\
& & & 49.9 \\
Marital status & Single & 238 & 47.5 \\
& Married & 231 & 46.1 \\
& Cohabiting & 31 & 6.2 \\
& Divorced & 1 & 0.2 \\
& & & \\
& $<20$ & 22 & 4.4 \\
& $20-29$ & 158 & 31.5 \\
& $30-39$ & 118 & 23.6 \\
& $40-49$ & 76 & 15.2 \\
& $>50$ & 127 & 25.3 \\
\hline
\end{tabular}


Table 3 Purpose of visit

\begin{tabular}{lcc}
\hline Purpose & Number of respondents & Percentage \\
\hline Visiting friends and & 130 & 25.9 \\
relatives & & \\
Holiday & 225 & 44.9 \\
Volunteering & 124 & 24.8 \\
Religion/ Mission & 22 & 4.4 \\
\hline
\end{tabular}


Table 4 Travel arrangement

\begin{tabular}{lcc}
\hline Travel arrangement type & Number of respondents & Percent \\
\hline Independents & 356 & 71.1 \\
Package tour & 65 & 13.0 \\
Volunteer company & 64 & 12.8 \\
Others & 16 & 3.2 \\
\hline Total & $\mathbf{5 0 1}$ & $\mathbf{1 0 0}$ \\
\hline
\end{tabular}

